\title{
24. COMPRESSIONAL AND SHEAR WAVE VELOCITIES IN BASALTIC ROCKS, DEEP SEA DRILLING PROJECT, LEG 16
}

\author{
Nikolas I. Christensen, University of Washington, Seattle
}

\section{INTRODUCTION}

Velocities have been measured as a function of hydrostatic pressure on cylindrical specimens 1.3 to $1.9 \mathrm{~cm}$ in diameter and 3.2 to $4.6 \mathrm{~cm}$ in length cut from basalts collected during Leg 16 of the Deep Sea Drilling Project. All velocities were measured at room temperature on water saturated samples. The laboratory techniques employed have been described in detail by Birch (1960) and Christensen and Shaw (1970).

The purposes of this study were: (a) to establish velocity-density relations for oceanic basement rocks, (b) compare the laboratory measured velocities with seismic refraction basement velocities, and (c) determine the possible vertical extent of oceanic basalts.

The samples selected represent extremes in densities and elastic properties of oceanic crustal basalt. The 16329-4(67-74) basalt is a massive, fresh basalt with an intergranular texture. To check for possible anisotropy in this specimen, velocites were measured both parallel and perpendicular to the core axis. The 155-11(143-150) sample is an altered vesicular basalt. Modal analyses obtained by point-counting thin sections cut from the samples used for the measurements are given in Table 1.

TABLE 1

Modal Analyses, Percentages by Volume

\begin{tabular}{lcc}
\hline \multicolumn{1}{c}{ Mineral } & $155-1-1(143-150)$ & $163-29-4(67-74)$ \\
\hline Plagioclase & 45 & 58 \\
Pyroxene & 40 & 9 \\
Olivine & 4 & - \\
Opaques & 8 & 10 \\
Others $^{\mathrm{a}}$ & 3 & 23 \\
\hline
\end{tabular}

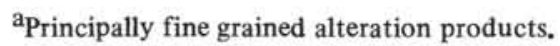

\section{RESULTS}

Compressional (P) and shear (S) wave velocities at pressures to $10 \mathrm{~kb}$ and bulk densities are given in Table 2 . The densities were calculated from the weights and dimensions of the samples. The data in Table 2 are uncorrected for length changes at elevated pressures, which lower the $10-\mathrm{kb}$ compressional and shear wave velocities by approximately 0.03 and $0.01 \mathrm{~km} / \mathrm{sec}$, respectively. At $10 \mathrm{~kb}$ the bulk densities in Table 2 are increased by approximately $0.03 \mathrm{~g} / \mathrm{cc}$.

The ratio of compressional to shear velocity $\left(\mathrm{V}_{\mathrm{p}} / \mathrm{V}_{\mathrm{s}}\right)$, Poisson's ratio $(\sigma)$, the seismic parameter $(\phi)$, the bulk modulus $(\mathrm{K})$, compressibility $(\beta)$, the shear modulus $(\mu)$, Young's modulus (E), and Lame's constant $(\tau)$ calculated at selected pressures for each rock are presented in Table 3 . The equations relating these constants to velocities and densities are summarized by Birch (1961). Velocities and densities used for the calculations were corrected for dimension changes using an iterative routine and the dynamically determined compressibilities. The elastic constants for the basalt from DSDP 163 were calculated from mean velocities and densities.

\section{VELOCITY-DENSITY RELATIONS}

One purpose of velocity measurements in rocks is to obtain information on the relationships of seismic velocities to rock densities. Once these relationships have been established, seismic refraction velocities can be interpreted in terms of crustal and mantle densities. A number of velocity-density correlations have been given for rocks at pressures to $10 \mathrm{~kb}$ (Birch, 1961; Christensen, 1966; Manghnani and Woollard, 1968; Christensen and Shaw, 1970). Solutions at 0.4 and $10 \mathrm{~kb}$ for fifty-seven cores of basaltic rock from the Mid-Atlantic Ridge reported by Christensen and Shaw (1970) are shown in Figure 1. Christensen and Shaw found that slopes of the linear

TABLE 2

Elastic Wave Velocities $(\mathrm{km} / \mathrm{sec})$

\begin{tabular}{|c|c|c|c|c|c|c|c|c|c|c|c|c|}
\hline \multirow[b]{2}{*}{ Number } & \multirow{2}{*}{$\begin{array}{c}\text { Bulk } \\
\text { Density }\end{array}$} & \multirow[b]{2}{*}{ Mode } & \multicolumn{10}{|c|}{ Pressure } \\
\hline & & & $0.2 \mathrm{~kb}$ & $0.4 \mathrm{~kb}$ & $0.6 \mathrm{~kb}$ & $0.8 \mathrm{~kb}$ & $1.0 \mathrm{~kb}$ & $2.0 \mathrm{~kb}$ & $4.0 \mathrm{~kb}$ & $6.0 \mathrm{~kb}$ & $8.0 \mathrm{~kb}$ & $10.0 \mathrm{~kb}$ \\
\hline $163 /$ & 2.935 & P & 6.345 & 6.360 & 6.373 & 6.385 & 6.395 & 6.438 & 6.497 & 6.519 & 6.568 & 6.589 \\
\hline $163 \mid$ & 2.937 & P & 6.358 & 6.377 & 6.393 & 6.407 & 6.420 & 6.463 & 6.522 & 6.565 & 6.596 & 6.616 \\
\hline Mean & 2.936 & $P$ & 6.352 & 6.369 & 6.383 & 6.396 & 6.407 & 6.451 & 6.501 & 6.542 & 6.582 & 6.603 \\
\hline $155 /$ & 2.448 & $\mathrm{P}$ & 4.157 & 4.188 & 4.218 & 4.242 & 4.266 & 4.356 & 4.480 & 4.561 & 4.614 & 4.641 \\
\hline $163 / \prime$ & 2.935 & $\mathrm{~S}$ & 3.464 & 3.479 & 3.488 & 3.495 & 3.500 & 3.519 & 3.538 & 3.550 & 3.558 & 3.560 \\
\hline $163 \mid$ & 2.937 & S & 3.545 & 3.560 & 3.575 & 3.585 & 3.593 & 3.613 & 3.630 & 3.638 & 3.643 & 3.647 \\
\hline Mean & 2.936 & S & 3.505 & 3.520 & 3.532 & 3.540 & 3.547 & 3.566 & 3.584 & 3.594 & 3.601 & 3.604 \\
\hline $155 /$ & 2.448 & $\mathrm{~S}$ & 2.025 & 2.037 & 2.048 & 2.058 & 2.070 & 2.107 & 2.153 & 2.178 & 2.193 & 2.200 \\
\hline
\end{tabular}


TABLE 3

Elastic Constants

\begin{tabular}{ccccccccc}
\hline $\begin{array}{c}\text { Pressure } \\
(\mathrm{kb})\end{array}$ & $\mathrm{V}_{\mathrm{p}} / \mathrm{V}_{\mathrm{s}}$ & $\sigma$ & $\begin{array}{c}\phi \\
(\mathrm{km} / \mathrm{sec})^{2}\end{array}$ & $\begin{array}{c}\mathrm{K} \\
\mathrm{Mb}\end{array}$ & $\underset{\mathrm{Mb}^{-1}}{\mathrm{~B}}$ & $\underset{\mathrm{Mb}}{\mu}$ & $\underset{\mathrm{Mb}}{\mathrm{E}}$ & $\underset{\mathrm{Mb}}{\lambda}$ \\
\hline
\end{tabular}

Basalt 155-11-1(143-150)

$\begin{array}{rllllllll}0.4 & 1.81 & 0.28 & 24.0 & 0.71 & 1.41 & 0.36 & 0.93 & 0.46 \\ 1.0 & 1.81 & 0.28 & 24.3 & 0.71 & 1.40 & 0.37 & 0.95 & 0.47 \\ 2.0 & 1.81 & 0.28 & 24.6 & 0.72 & 1.37 & 0.37 & 0.96 & 0.48 \\ 6.0 & 1.82 & 0.28 & 25.4 & 0.75 & 1.32 & 0.38 & 0.98 & 0.50 \\ 10.0 & 1.83 & 0.29 & 26.0 & 0.77 & 1.29 & 0.38 & 0.99 & 0.52\end{array}$

Basalt 163-29-4(67-74)

\begin{tabular}{rrrrrrrrr}
0.4 & 2.06 & 0.35 & 12.0 & 0.29 & 3.40 & 0.10 & 0.27 & 0.23 \\
1.0 & 2.06 & 0.35 & 12.5 & 0.31 & 3.26 & 0.11 & 0.28 & 0.24 \\
2.0 & 2.07 & 0.35 & 13.0 & 0.32 & 3.12 & 0.11 & 0.29 & 0.25 \\
6.0 & 2.09 & 0.35 & 14.3 & 0.36 & 2.80 & 0.12 & 0.32 & 0.28 \\
10.0 & 2.11 & 0.36 & 14.8 & 0.37 & 2.68 & 0.12 & 0.32 & 0.29 \\
\hline
\end{tabular}

velocity-density least-squares, solutions decrease with increasing pressure. This was interpreted as being due to grain boundary porosity effects at lower pressures, which have a large influence on velocities in relatively low-density basalts.

Compressional wave velocities for the basalts from DSDP 155 and 163 are compared in Figure 1 with those of the Mid-Atlantic Ridge rocks. For both basalts the $10-\mathrm{kb}$ velocities are approximately $0.2 \mathrm{~km} / \mathrm{sec}$ lower than velocities for average Mid-Atlantic Ridge rocks with equivalent densities. Compressional wave velocity at $10 \mathrm{~kb}$ for a water saturated basalt from the Juan de Fuca Ridge (Christensen, 1970a) is also slightly lower than that of the Mid-Atlantic Ridge basalts. Whether or not this relationship will hold for a majority of Pacific basalts will require additional measurements.

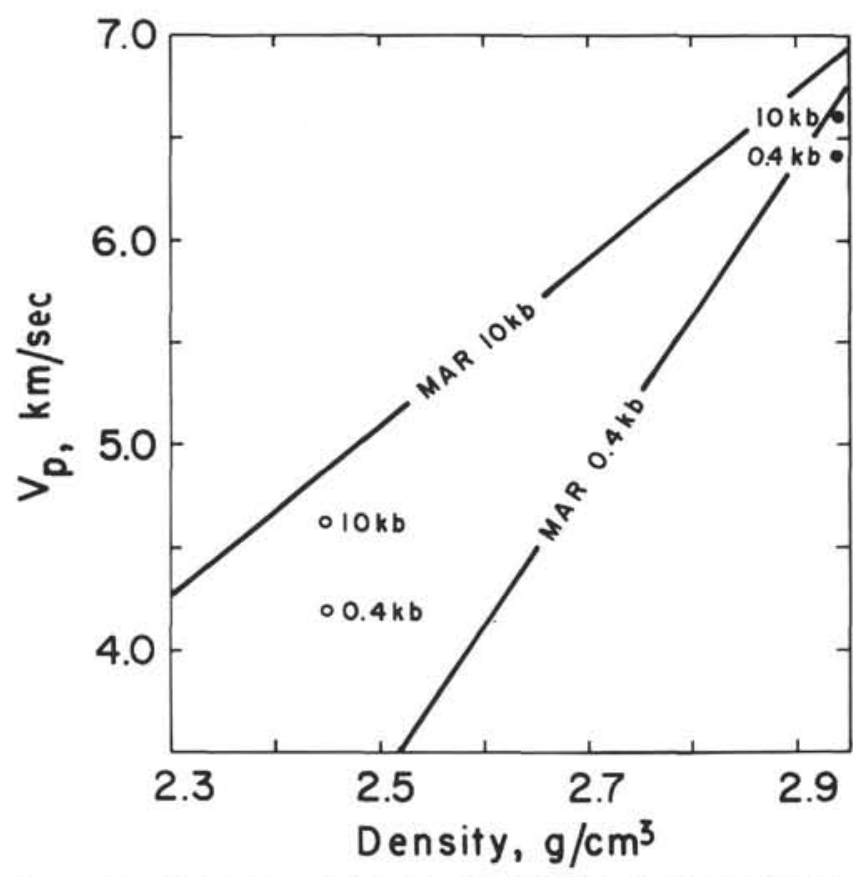

Figure 1. Velocities and densities at 0.4 and $10 \mathrm{~kb}$ for basalts 155-11-1(143-150)(open circles) and 163-29-4/6774) (solid circles) compared with Mid-Atlantic Ridge basaltic rocks.
The compressional wave velocity at $0.4 \mathrm{~kb}$ for the basalt from DSDP 163 is also lower than the least-squares solution for the Mid-Atlantic Ridge basalts (Figure1). The 0.4-kb velocity for basalt DSDP 155 , however, falls well above the 0.4-kb line. The Mid-Atlantic Ridge basaltic rocks from which the least-squares solution were obtained varied in bulk density from 2.69 to $2.89 \mathrm{~g} / \mathrm{cc}$, whereas sample DSDP 155 has a density of $2.45 \mathrm{~g} / \mathrm{cc}$. Thus it appears that at $0.4 \mathrm{~kb}$, the velocity-density curve is parabolic such that low-density basalts in the range of 2.4 to $2.6 \mathrm{~g} / \mathrm{cc}$ have similar compressional wave velocities. These relatively high velocities at low pressure are probably due in part to alteration which has eliminated much of the grain boundary poiosity effects on low-pressure velocities and at the same time has decreased density. In the intermediate density range of approximately 2.6 to $2.8 \mathrm{~g} / \mathrm{cc}$, porosity appears to have a maximum effect on low-pressure velocities. Velocity-density relations at higher pressures are, however, linear, due to closure of pore space.

\section{PACIFIC CRUSTAL COMPOOSITION}

The measurements in Table 2 offer the unique opportunity for direct comparisons of oceanic basement compressional wave velocities determined by seismic refraction studies with laboratory measured velocities in samples that represent oceanic basement. Several seismic refraction studies of oceanic crustal structure have been carried out in the Pacific basin (for a summary of data to 1969, see Shor et al., 1971), and a limited number of profiles have been published in the vicinities of DSDP 155 and 163 (Table 4).

Basement velocities in the Pacific basin commonly range from 4.0 to $6.4 \mathrm{~km} / \mathrm{sec}$ and average $5.2 \mathrm{~km} / \mathrm{sec}$ (Shor et al., 1971). Shor et al. (1971) attribute part of the scatter in velocities to inaccuracy in the refraction data and also suggest that some of the scatter may be due to interlayering of low-velocity sediments with the basement basalts. From the data in Table 2 it is evident that the range in velocities reported for the oceanic basement also can be accounted for by different degrees of alteration, perhaps in combination with variable vesicularity.

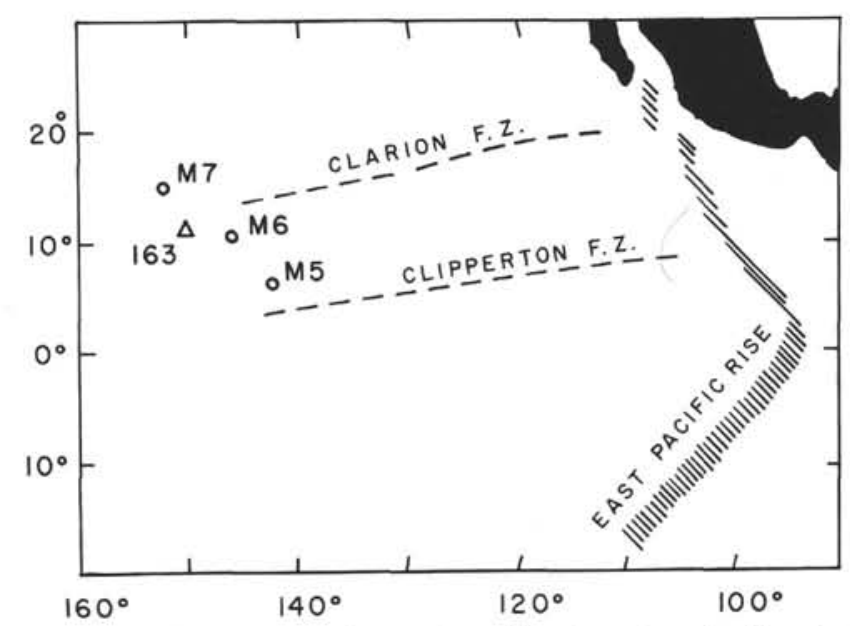

Figure 2. Locations of seismic refraction data in the vicinity of DSDP 163. 
TABLE 4

Seismrc Velocities $(\mathrm{km} / \mathrm{sec})$ and Layer Thicknesses $(\mathrm{km})$

in the Vicinities of DSDP 163 and 155

\begin{tabular}{r|r|c|c|c|c|c|c|c|c}
\hline \multicolumn{2}{c|}{ Location } & Water & \multicolumn{2}{|c|}{ Sediment } & \multicolumn{2}{c|}{ Basement } & \multicolumn{2}{c}{ Crust } & \multirow{2}{*}{ Reference } \\
\hline Lat. N & Long. W & $\mathrm{h}$ & $\mathrm{h}$ & $\mathrm{V}_{\mathrm{p}}$ & $\mathrm{h}$ & $\mathrm{V}_{\mathrm{p}}$ & $\mathrm{h}$ & $\mathrm{V}_{\mathrm{p}}$ & ( \\
\hline $5^{\circ} 51^{\prime}$ & $141^{\circ} 51^{\prime}$ & 4.81 & 0.57 & 2.15 & 1.16 & 6.32 & - & 6.79 & M5 - Raitt, 1956 \\
$10^{\circ} 43^{\prime}$ & $145^{\circ} 53^{\prime}$ & 5.25 & 0.20 & 2.15 & - & - & 4.42 & 6.58 & M6 - Raitt, 1956 \\
$14^{\circ} 41^{\prime}$ & $151^{\circ} 54^{\prime}$ & 5.80 & 0.32 & 2.15 & 0.81 & 6.04 & 4.14 & 6.73 & M7 - Raitt, 1956 \\
$9^{\circ} 48^{\prime}$ & $93^{\circ} 12^{\prime}$ & 3.74 & 0.11 & 2.15 & 1.45 & 4.32 & 4.13 & 6.84 & CH8 - Shor et al., 1971 \\
\hline
\end{tabular}

Seismic refraction stations M5, M6, and M7 reported by Raitt (1956) are located in the vicinity of DSDP 163 (Figure 2). Basement velocities unfortunately were not obtained for station M6 which is closest to DSDP 163. However, stations M5 and M7 have basement velocities of over $6 \mathrm{~km} / \mathrm{sec}$ (Table 4), which are well above the Pacific average. With a water depth of $5.3 \mathrm{~km}$ and a sediment thickness of $0.3 \mathrm{~km}$, the pressure in the upper basement at DSDP 163 would be approximately $0.6 \mathrm{~kb}$. The compressional wave velocity at $0.6 \mathrm{~kb}$ measured for the basement rock at this station is $6.38 \mathrm{~km} / \mathrm{sec}$ (Table 2), which is an excellent agreement with the seismic refraction data.

Shor and Fisher (1961) have reported oceanic crustal structure along the Middle America Trench. For several of their stations between $85^{\circ} \mathrm{W}$ and $95^{\circ} \mathrm{W}$ basement arrivals were not observed. However, two stations (4 and $\left.4^{\prime}\right)$ between $90^{\circ} \mathrm{W}$ and $93^{\circ} \mathrm{W}$ have basement velocities of 4.40 $\mathrm{km} / \mathrm{sec}$. These stations were located on the shelf between Champerico and the Middle America Trench. Shor et al. (1971) have also reported a basement velocity of 4.32 $\mathrm{km} / \mathrm{sec}$ south of the Middle America Trench at $93^{\circ} \mathrm{W}$ (Table 4). Basement velocities in this region, therefore, appear to be lower than those for average basement, which correlates well with the measured velocities in the basalt from DSDP 155. Upper basement pressure at DSDP 155 is approximately $0.4 \mathrm{~kb}$, and the compressional wave velocity of the basalt from DSDP 155 at $0.4 \mathrm{~kb}$ is 4.19 $\mathrm{km} / \mathrm{sec}$ (Table 2).

A comparison of the basalt velocities with the refraction data in Table 4 clearly demonstrates that the basalts from DSDP 155 and 163 are not major constituents of the lower oceanic crustal layer. This is in accord with earlier studies of oceanic rocks by Christensen (1970b) and Christensen and Shaw (1970).

\section{ACKNOWLEDGMENT}

Financial support for this study was provided by NSF grant GA-20317.

\section{REFERENCES}

Birch, F., 1960. The velocity of compressional waves in rocks to 10 kilobars, 1. J. Geophys. Res. 65, 1083.

,1961. The velocity of compressional waves in rocks to 10 kilobars, 2. J. Geophys. Res. 66, 2199.

Christensen, N.I., 1966. Elasticity of ultrabasic rocks. J. Geophys. Res. 71, 5921.

1970a. Compressional wave velocities in basalts from the Juan de Fuca Ridge. J. Geophys. Res. 75, 2773. 1970b. Composition and evolution of the oceanic crust. Marine Geol. 8, 139.

Christensen, N.I. and Shaw, G.H., 1970. Elasticity of mafic rocks from the Mid-Atlantic Ridge. Geophys. J. Roy. Astro. Soc. 20, 271.

Manghnani, M.H. and Woollard, G.P., 1968. Elastic wave velocities in Hawaiian rocks at pressures to 10 kilobars. In The Crust and Upper Mantle of the Pacific Area. L. Knopoff, C.L. Drake, and P.J. Hart (Eds.). Am. Geophys. Union Monogr. 12, 501 .

Raitt, R.W., 1956. Seismic-refraction studies of the Pacific Ocean basin. Bull. Geol. Soc. Am. 67, 1623.

Shor, G.G., Jr. and Fisher, R.L., 1961. Middle America trench: seismic-refraction studies. Bull. Geol. Soc. Am. 72, 721.

Shor, G.G., Jr., Menard, H.W. and Raitt, R.W., 1971. Stucture of the Pacific basin. In The Sea. A.E. Maxwell (Ed.), 4, P. II. New York (Wiley-Interscience), 3. 